\title{
Management Accounting Tools and Application Cases - Resource Consumption Accounting Method and Application
}

\author{
Liu Yijuan ${ }^{1, a}$, Wang Ting ${ }^{2, b}$ \\ ${ }^{1}$ Nanjing University of Science and Technology, China \\ ${ }^{2}$ Nanjing University of Science and Technology,China \\ aliuynjust@163.com, b13770734199@163.com \\ Corresponding author: Wang Ting
}

Keywords:Activity based costing, Elastic marginal cost method, Resource consumption accounting.

\begin{abstract}
With the rapid development of economy and technology, the traditional activity-based costing method is difficult to reflect the utilization effect of resources, and cannot reflect the initial state of the inherent cost, it is difficult to meet the need of management decision-making, cost accounting innovation is imperative. Resource consumption accounting is a new cost accounting method which is based on the activity-based costing method and the German flexible marginal cost method. It is a great innovation of cost accounting in recent years. This paper is based on the introduction of the basic principles of resource consumption accounting, explains the accounting process of resource consumption accounting and provides reference for the future application of resource consumption accounting in enterprises by taking $Q$ enterprise as an example.
\end{abstract}

\section{The introduction}

In recent years, with the rapid development of economy and science and technology, the competition among enterprises is becoming more and more fierce. In this environment, the key to maximizing the value of the business is to strengthen the control of the cost, so the choice of cost accounting method is essential for the enterprise. Resource Consumption Accounting (RCA) is a resource-oriented approach to cost accounting, which improves the traditional activity-based costing method, not only from the internal work-based costing method, but also from the external resources Angle to enhance the cost management of the strategic system. The method which uses the resource as the main accounting object can measure the idle resources, not only improving the accuracy of the cost accounting, but also providing information on the responsibility of the department to assess. So it is conducive to enterprises to make scientific and rational decision-making, and enhance their own competitive advantage.

\section{Characteristics of Resource Consumption Accounting}

Although the traditional activity-based costing method also follows the concept of "product consumption operation and operating resource consumption", the activity-based costing focuses on operation while the resource consumption accounting focuses on resource. Compared with the traditional operating cost method, the cost accounting of resource consumption accounting is more accurate, the measurement standard is more comprehensive and the understanding of cost performance is more profound. This is mainly reflected in the following aspects.

2.1 The Main Accounting Object of Resource Consumption Accounting is resource. The resource here is a broad concept that refers to the cost transfer between departments, not only the resources consumed by the job, but also the resources that the resource consumes, so the resource drivers not only include the "resource - operation" direct allocation of resource drivers, but also include the "resource - resources" of the interactive allocation of resources drivers. Resource consumption accounting can not only calculate the resources used in production, but also to measure the idle resources. So it can assign responsibility to each responsible person through the 
allocation of idle resource costs, which is conducive to cost management and performance appraisal.

2.2 Resource Consumption Accounting Uses Both Quantity and Amount to Measure Resource Consumption. Resource consumption accounting uses two measurement standards because only using the amount of money is difficult to fully reflect the consumption of resources and difficult to show the number of idle resources. In the amount of energy consumption in the measurement, and then converted into the amount of measurement, so as to facilitate the cost of accounting. This way of re-calculating the cost of the first metering resource consumption helps both the analysis of idle resources and the analysis of the cost differences between the budget and the actual business.

2.3 Under Resource Consumption Accounting, Costs are Divided into Fixed and Variable Costs. The division of cost behavior is also a major feature of resource consumption accounting. The division of the fixed cost and variable cost of should consider from the resource supply and resource consumption two aspects. First, from the point of view of resource supply, the variable cost will vary as the output changes, and the fixed costs will not. Second, from the point of view of resource consumption, even if the initial cost of a cost is a variable cost, it will become a fixed cost if its output consumption is fixed. And for the costs whose initial state is fixed costs, resource consumption accounting principle is that once it is identified as fixed, it has been fixed.

\section{Application Examples of Resource Consumption Accounting in Q Enterprise}

Based on the advantages of resource consumption accounting, this paper applies it to Q enterprises, and calculates the cost of products, then gets the cost information of A products and B products.

Q company is a clothing production Co., Ltd which has a basic production workshop, a maintenance workshop and a administrative department. Basic production workshop has 4 managers, 200 workers and 215 machines, each machine's price is 12000 yuan, depreciated in 10 years. Maintenance workshop has 1 managers, 5 maintenance workers.

3.1 Divide the Cost Center. The basic production workshop and auxiliary production workshop are divided into basic cost center and auxiliary cost center.

3.2 Assign Resources which Have Been Consumed to Cost Centers and Differentiate Cost Nature. The salary of managers in basic production workshop is 5000 yuan every month, it is a fixed cost. The wages of workers is a variable cost. Electricity cost is variable cost and machine depreciation cost is fixed cost. The resource pooling method of the Auxiliary Cost Center is the same as the resource pooling method of the basic cost center. The information is shown in table 1, and table 2 .

Table 1 The information of basic cost center

\begin{tabular}{c|c|c|c|c}
\hline \multirow{2}{*}{} & \multicolumn{2}{|c|}{ Actual } & \multicolumn{2}{c}{ Budget } \\
\cline { 2 - 5 } & Fixed cost & $\begin{array}{c}\text { Variable } \\
\text { cost }\end{array}$ & Fixed cost & $\begin{array}{c}\text { Variable } \\
\text { cost }\end{array}$ \\
\hline $\begin{array}{c}\text { Managers' salary } \\
\text { (yuan) }\end{array}$ & 20000 & & 20000 & \\
\hline $\begin{array}{c}\text { Workers' salary } \\
\text { (yuan) }\end{array}$ & & 780000 & & 810000 \\
\hline $\begin{array}{c}\text { Electricity fee } \\
\text { (yuan) }\end{array}$ & 21500 & 8500 & & 9000 \\
\hline $\begin{array}{c}\text { Depreciation } \\
\text { expense (yuan) }\end{array}$ & 41500 & 788500 & 41500 & 819000 \\
\hline \begin{tabular}{c} 
Total (yuan) \\
\hline
\end{tabular}
\end{tabular}


Table 2 The information of auxiliary cost center

\begin{tabular}{c|c|c|c|c}
\hline \multirow{2}{*}{} & \multicolumn{2}{|c|}{ Actual } & \multicolumn{2}{c}{ Budget } \\
\cline { 2 - 5 } & $\begin{array}{c}\text { Fixed } \\
\text { cost }\end{array}$ & $\begin{array}{c}\text { Variable } \\
\text { cost }\end{array}$ & $\begin{array}{c}\text { Fixed } \\
\text { cost }\end{array}$ & $\begin{array}{c}\text { Variable } \\
\text { cost }\end{array}$ \\
\hline Managers' salary (yuan) & 5000 & & 5000 & \\
\hline Workers' salary (yuan) & & 20800 & & 22500 \\
\hline Electricity fee (yuan) & & 520 & & 580 \\
\hline Depreciation expense (yuan) & 11000 & & 11000 & 23080 \\
\hline Total (yuan) & 16000 & 21320 & 16000 & 20.52 \\
\hline $\begin{array}{c}\text { The amount of operations (artificial } \\
\text { hour) }\end{array}$ & & 1040 & & 1125 \\
\hline $\begin{array}{c}\text { Unit cost (yuan/hour) } \\
\text { The amount of Idle operations } \\
\text { (artificial hour) }\end{array}$ & 15.38 & 20.50 & 14.22 & 2 \\
\hline Idle operating costs (yuan) & \multicolumn{5}{|c}{85} \\
\hline
\end{tabular}

3.3 Assign the Cost of the Auxiliary Cost Center to the Basic Cost Center. Because the repair workshop is dedicated to the basic production workshop, so the maintenance cost should be assigned to the basic production center. The information is shown in table 3 .

Table 3 Relevant information of basic production workshop after transferring maintenance fee

\begin{tabular}{c|c|c|c|c}
\hline & \multicolumn{2}{|c|}{ Actual } & \multicolumn{2}{c}{ Budget } \\
\cline { 2 - 5 } & Fixed cost & $\begin{array}{c}\text { Variable } \\
\text { cost }\end{array}$ & Fixed cost & $\begin{array}{c}\text { Variable } \\
\text { cost }\end{array}$ \\
\hline Managers' salary (yuan) & 20000 & & 20000 & \\
\hline Workers' salary (yuan) & & 780000 & & 810000 \\
\hline Electricity fee (yuan) & & 8500 & & 9000 \\
\hline $\begin{array}{c}\text { Depreciation expense } \\
\text { (yuan) }\end{array}$ & 21500 & & 21500 & \\
\hline $\begin{array}{c}\text { Transfer maintenance } \\
\text { charge (yuan) }\end{array}$ & 16000 & 21320 & 16000 & 23080 \\
\hline Total (yuan) & 57500 & 809820 & 57500 & 842080 \\
\hline
\end{tabular}

3.4 Separate Resource Collection Points in the Basic Cost Center. The resource collection point of the basic production workshop can be divided into the human resource collection point and the machine equipment resource collection point. Managers 'salary and workers' wages are related to human resources and should be pooled into human resource collection point. Electricity, depreciation and maintenance costs are related to machinery and equipment. They should be included in the machine equipment resource collection point. In this garment factory, a worker operates a machine so that the output of the human resource is the same as the output of the machine. The relevant information is shown in table 4 , table 5. 
Table 4 Human resource collection point

\begin{tabular}{|c|c|c|c|c|}
\hline & \multicolumn{2}{|c|}{ Actual } & \multicolumn{2}{|c|}{ Budget } \\
\hline & Fixed cost & $\begin{array}{c}\text { Variable } \\
\text { cost }\end{array}$ & Fixed cost & $\begin{array}{c}\text { Variable } \\
\text { cost }\end{array}$ \\
\hline Managers' salary（yuan） & 20000 & & 20000 & \\
\hline Workers' salary（yuan） & & 780000 & & 810000 \\
\hline Total（yuan） & 20000 & 780000 & 20000 & 810000 \\
\hline Output（artificial hour） & \multicolumn{2}{|c|}{46800} & \multicolumn{2}{|c|}{49000} \\
\hline Unit cost（yuan/hour） & 0.43 & 16.67 & 0.41 & 16.53 \\
\hline
\end{tabular}

Table 5 Equipment resource collection point

\begin{tabular}{|c|c|c|c|c|}
\hline & \multicolumn{2}{|c|}{ Actual } & \multicolumn{2}{|c|}{ Budget } \\
\hline & Fixed cost & $\begin{array}{c}\text { Variable } \\
\text { cost }\end{array}$ & Fixed cost & $\begin{array}{c}\text { Variable } \\
\text { cost }\end{array}$ \\
\hline Electricity fee (yuan) & & 8500 & & 9000 \\
\hline Depreciation expense (yuan) & 21500 & & 21500 & \\
\hline maintenance charge (yuan) & 16000 & 21320 & 16000 & 23080 \\
\hline Total (yuan) & 37500 & 29820 & 37500 & 32080 \\
\hline Output (machine hour) & \multicolumn{2}{|c|}{46800} & \multicolumn{2}{|c|}{49000} \\
\hline Unit cost（yuan/hour） & 0.80 & 0.64 & 0.77 & 0.65 \\
\hline
\end{tabular}

3.5 Assign the Cost in the Resource Collection Point to the Operation. The operations of the basic production workshop consist of two tasks, namely, production preparation and sewing. The information is shown in table 6 , table 7.

Table 6 Production preparation operation

\begin{tabular}{|c|c|c|c|c|c|}
\hline & \multicolumn{2}{|c|}{ Actual } & \multicolumn{2}{|c|}{ Budget } \\
\hline & & $\begin{array}{c}\text { Fixed } \\
\text { cost }\end{array}$ & $\begin{array}{c}\text { Variable } \\
\text { cost }\end{array}$ & $\begin{array}{c}\text { Fixed } \\
\text { cost }\end{array}$ & $\begin{array}{c}\text { Variable } \\
\text { cost }\end{array}$ \\
\hline \multirow{2}{*}{$\begin{array}{l}\text { Human } \\
\text { resource }\end{array}$} & $\begin{array}{l}\text { Consumption } \\
\text { (artificial hour) }\end{array}$ & \multicolumn{2}{|c|}{2340} & \multicolumn{2}{|c|}{2420} \\
\hline & $\begin{array}{c}\text { Distribution amount } \\
\text { (yuan) }\end{array}$ & 1000 & 39000 & 987.76 & 40004.08 \\
\hline \multirow{2}{*}{$\begin{array}{l}\text { Machine } \\
\text { resource }\end{array}$} & $\begin{array}{l}\text { Consumption } \\
\text { (machine hour) }\end{array}$ & \multicolumn{2}{|c|}{2340} & \multicolumn{2}{|c|}{2420} \\
\hline & $\begin{array}{c}\text { Distribution amount } \\
\text { (yuan) }\end{array}$ & 1875 & 1491 & 1852.04 & 1584.36 \\
\hline \multicolumn{2}{|c|}{ Total $($ yuan $)$} & 2875 & 40491 & 2839.8 & 41588.44 \\
\hline \multicolumn{2}{|c|}{$\begin{array}{l}\text { The amount of operation } \\
\text { ( second) }\end{array}$} & \multicolumn{2}{|c|}{42800} & \multicolumn{2}{|c|}{45000} \\
\hline
\end{tabular}




\begin{tabular}{c|c|c|c|c}
\hline Unit cost (yuan/second) & 0.07 & 0.95 & 0.06 & 0.92 \\
\hline $\begin{array}{c}\text { The amount of idle operation } \\
\text { ( second) }\end{array}$ & \multicolumn{4}{|c}{2200} \\
\hline $\begin{array}{c}\text { The cost of idle operation } \\
\text { (yuan) }\end{array}$ & \multicolumn{3}{|c}{138.83} \\
\hline
\end{tabular}

Table 7 Sewing operation

\begin{tabular}{|c|c|c|c|c|c|}
\hline & \multicolumn{2}{|c|}{ Actual } & \multicolumn{2}{|c|}{ Budget } \\
\hline & & Fixed cost & Variable cost & $\begin{array}{l}\text { Fixed } \\
\text { cost }\end{array}$ & $\begin{array}{c}\text { Variable } \\
\text { cost }\end{array}$ \\
\hline \multirow{2}{*}{$\begin{array}{l}\text { Human } \\
\text { resource }\end{array}$} & $\begin{array}{l}\text { Consumption } \\
\text { (artificial hour) }\end{array}$ & \multicolumn{2}{|c|}{44460} & \multicolumn{2}{|c|}{46580} \\
\hline & $\begin{array}{c}\text { Distribution amount } \\
\text { (yuan) }\end{array}$ & 19000 & 741000 & 19012.24 & 769995.92 \\
\hline \multirow{2}{*}{$\begin{array}{l}\text { Machine } \\
\text { resource }\end{array}$} & $\begin{array}{l}\text { Consumption } \\
\text { (machine hour) }\end{array}$ & \multicolumn{2}{|c|}{44460} & \multicolumn{2}{|c|}{46580} \\
\hline & $\begin{array}{l}\text { Distribution amount } \\
\text { (yuan) }\end{array}$ & 35625 & 28329 & 35647.96 & 30495.64 \\
\hline \multicolumn{2}{|c|}{ Total（yuan） } & 54625 & 769329 & 54660.2 & 800491.56 \\
\hline \multicolumn{2}{|c|}{$\begin{array}{l}\text { The amount of operation } \\
\text { ( second) }\end{array}$} & \multicolumn{2}{|c|}{42800} & \multicolumn{2}{|c|}{45000} \\
\hline \multicolumn{2}{|c|}{ Unit cost（yuan/second） } & 1.28 & 17.97 & 1.21 & 17.79 \\
\hline \multicolumn{2}{|c|}{$\begin{array}{l}\text { The amount of idle operation } \\
\text { ( second) }\end{array}$} & \multicolumn{4}{|c|}{2200} \\
\hline \multicolumn{2}{|c|}{ The cost of idle operation (yuan) } & \multicolumn{4}{|c|}{2672.28} \\
\hline
\end{tabular}

3.6 Assign the Cost of the Operations to the Product. The clothing factory produced two kinds of products, that is A products and B products. A products' budget production is 18500 and the actual output is 18250 . A products actually consumed production preparation and sewing operations 18,500 times, producing 250 pieces of nonconforming products. B products' budget production is 25200 and the actual output is 24000 .B products actually consumed production preparation and sewing operations 24300 times, producing 300 pieces of nonconforming products. The relevant information is shown in table 8 , table 9 .

Table 8 The cost of product A

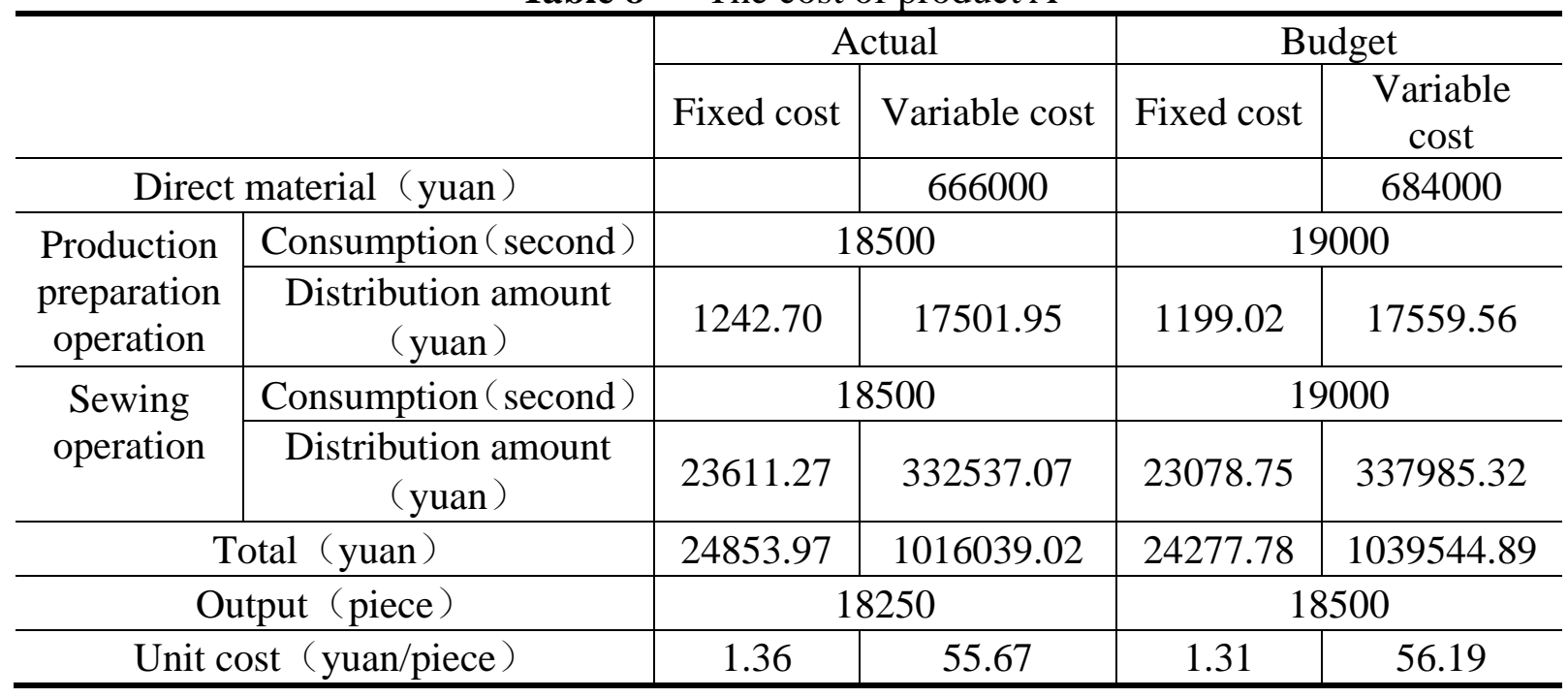


Table 9 The cost of product B

\begin{tabular}{|c|c|c|c|c|c|}
\hline & & \multicolumn{2}{|c|}{ Actual } & \multicolumn{2}{|c|}{ Budget } \\
\hline & & $\begin{array}{c}\text { Fixed } \\
\text { cost }\end{array}$ & Variable cost & $\begin{array}{c}\text { Fixed } \\
\text { cost }\end{array}$ & Variable cost \\
\hline \multicolumn{2}{|c|}{ Direct material（yuan） } & & 364500 & & 390000 \\
\hline \multirow{2}{*}{$\begin{array}{l}\text { Production } \\
\text { preparation } \\
\text { operation }\end{array}$} & Consumption ( second) & \multicolumn{2}{|c|}{24300} & \multicolumn{2}{|c|}{26000} \\
\hline & $\begin{array}{c}\text { Distribution amount } \\
(\text { yuan })\end{array}$ & 1632.30 & 22989.05 & 1640.77 & 24028.88 \\
\hline \multirow{2}{*}{$\begin{array}{l}\text { Sewing } \\
\text { operation }\end{array}$} & Consumption ( second) & \multicolumn{2}{|c|}{24300} & \multicolumn{2}{|c|}{26000} \\
\hline & \begin{tabular}{|c|}
$\begin{array}{c}\text { Distribution amount } \\
\text { (yuan })\end{array}$ \\
\end{tabular} & 31013.73 & 436791.93 & 31581.45 & 462506.23 \\
\hline \multicolumn{2}{|c|}{ Total $($ yuan $)$} & 32646.03 & 824280.98 & 33222.22 & 876535.11 \\
\hline \multicolumn{2}{|c|}{ Output (piece) } & \multicolumn{2}{|c|}{24000} & \multicolumn{2}{|c|}{25200} \\
\hline \multicolumn{2}{|c|}{ Unit cost（yuan/piece $)$} & 1.36 & 34.35 & 1.32 & 34.78 \\
\hline
\end{tabular}

As can be seen from the table, the unit cost of product $A$ is 57.03 yuan, of which the fixed cost is 1.36 yuan, the variable cost is 55.67 yuan, the unit cost of product B is 35.71 yuan, of which the fixed cost is 1.36 yuan, the variable cost is 34.35 yuan.

\section{Conclusion}

Resource consumption accounting can not only calculate the idle resources and idle production capacity, but also it can provide the information of fixed cost and variable cost. It is not only beneficial to the enterprise performance measurement and evaluation, but also conducive to the calculation and analysis of marginal benefit. At present, the application of resource consumption accounting in enterprises is still in the exploratory stage. The current research mainly focuses on the application of the method in the manufacturing industry, service industry and coal coking industry. In view of the advantages of resource consumption accounting in cost accounting and performance evaluation, with the development of information technology and the popular application of ERP in Enterprises, Resource consumption accounting will be used in many other industries.

\section{References}

[1] Feng Q G. Resource Consumption Accounting[J]. Journal of Shanghai Lixin University of Commerce, 2008, 448-453(4):63-77.

[2] Anton V D M, Keys D E. THE CASE FOR Resource Consumption Accounting[J]. Strategic Finance, 2002.

[3] Webber S. Resource Consumption Accounting Applied: The Clopay Case: In the October 2004 Issue of Strategic Finance, We Introduced a Case Study of Resource Consumption Accounting (RCA) Conducted by the RCA Interest Group of the Consortium for Advanced Manufacturing-I[J]. Management Accounting Quarterly, 2004, 37(6):807-824.

[4] Tse M S C, Gong M Z. Recognition of Idle Resources in Time-Driven Activity-Based Costing and Resource Consumption Accounting Models[J]. Journal of Applied Management Accounting Research, 2009, 7(2):41-54.

[5] White L. Resource consumption accounting: Manager-focused management accounting[J]. Journal of Corporate Accounting \& Finance, 2010, 20(4):63-77.

[6] Clinton B D, Webber S A. RCA at Clopay: Here's Innovation in Management Accounting with Resource Consumption Accounting[J]. Strategic Finance, 2004(October).

[7] Feng Q. Cost Accounting Innovation and the Resource Consumption Accounting[J]. 
Accounting Research, 2006, 18(12):33-40.

[8] Perkins D, Stovall O S. Resource Consumption Accounting Where Does It Fit?[J]. Journal of Applied Business Research, 2011, 27(5):41-52. 